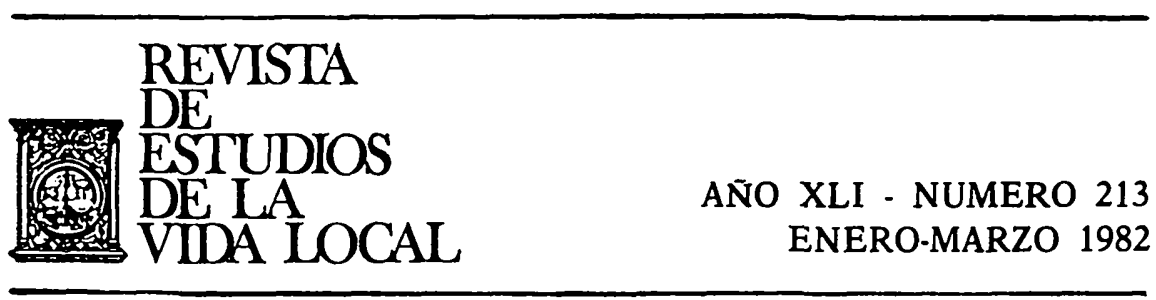

\title{
sumario
}

Págs.

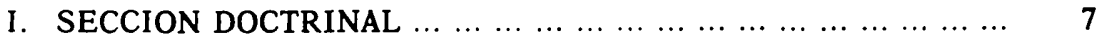

Juan-Luis de Simón Tobalina: El proyecto de Ley de Bases de la

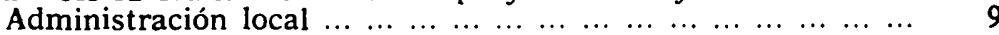

Vicente de la Vallina Velarde: Consideraciones sobre la auto-

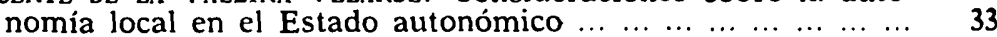

Alfredo Iglesias Suárez: La Hacienda de Galicia. Una breve apro$\begin{array}{lllllllll}\text { ximación histórica } & \ldots & \ldots & \ldots & \ldots & \ldots & \ldots & \ldots & \ldots\end{array}$

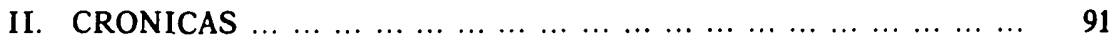

ANTONIo Rodríguez Socorro: Desequilibrios regionales autonómicos y criterios para la distribución del Fondo de Compensación Interterritorial .

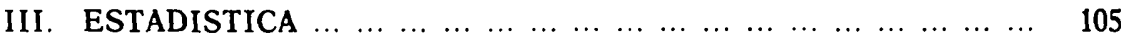

IgNacio Ballester Ros: Evolución de la población española en el período 1971-1981

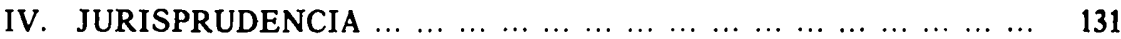

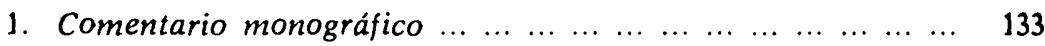

Nemesio Rodrf́guez Moro: La autonomía de los Entes territoriales locales en la Constitución española de 27 de diciembre de $\begin{array}{lllllllllllllllllllll}1978 & \ldots & \ldots & \ldots & \ldots & \ldots & \ldots & \ldots & \ldots & \ldots & \ldots & \ldots & \ldots & \ldots & \ldots & \ldots & \ldots & \ldots & \ldots & \ldots & 133\end{array}$

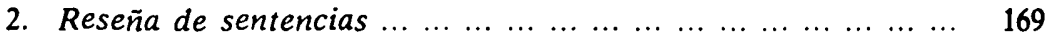

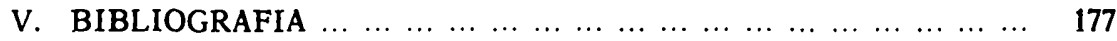

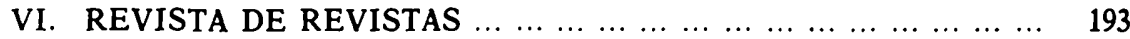


REVL-1982, núm. 213. SUMARIO 


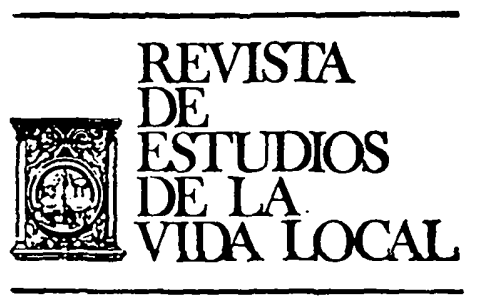

\section{SECCION DOCTRINAL}


REVL-1982, núm. 213. SUMARIO 